\title{
General Characteristics of Practices and Non-Practices Farmers and Their Opinions on Good Agriculture Practice in Adana Province
}

\author{
Hilal Yilmaz ${ }^{1, a, *}$, Cengiz Sağlam ${ }^{1, b}$, Mevlüt Güll ${ }^{2, c}$, Başak Aydin ${ }^{3, d}$, Tugay Ayasan ${ }^{4, e}$ \\ ${ }^{1}$ East Mediterranean Agricultural Research Institute, 01370 Dogankent/Yuregir/Adana, Turkey \\ ${ }^{2}$ Department of Agricultural Economics, Isparta University of Applied Science, Faculty of Agriculture, 32260 Isparta, Turkey \\ ${ }^{3}$ Ataturk Soil and Water Agricultural Meteorology Research Institute, 39000 Kırklareli, Turkey \\ ${ }^{4}$ Kadirli Academy of Applied Sciences, Osmaniye Korkut Ata University, 80750 Osmaniye, Turkey \\ *Corresponding author
}

\begin{tabular}{l|l}
\hline A R T I C L E I N F O & A B S T R A C T \\
Research Article & $\begin{array}{l}\text { The agricultural production model which is done in order to provide food security, sustainability, } \\
\text { and traceability in the agriculture, protect the natural sources and perform agricultural production, } \\
\text { harmless to the environment, human and animal health, is called as Good Agricultural Practices. } \\
\text { This study covers agricultural enterprises engaged in good agricultural practices and non-engaged } \\
\text { in good agricultural practices in Adana province. The aim of the research is to compare the general } \\
\text { characteristics of farms and to determine their views on good agricultural practices. The main } \\
\text { material of the study constituted the primary data obtained through the survey of the 170 enterprises } \\
\text { engaged in good agricultural and the non-used citrus (lemon and mandarin) farming in Adana } \\
\text { province. According to the survey, it was determined that a higher level of education in enterprises } \\
\text { engaged in ITU. The majority of good agricultural producers are residents in cities and towns and } \\
\text { have social security. About } 84.71 \% \text { of good agricultural producers practise ITU in order to benefit } \\
\text { support. It was determined that } 25.88 \% \text { of no good agriculture practices found ITU unnecessary. The } \\
67.06 \% \text { of producers stated that the market situation of the ITU products is similar to conventional } \\
\text { Accepted : 05/11/2019 }\end{array}$ \\
$\begin{array}{l}\text { Keywords: } \\
\text { Good agricultural practices } \\
\text { Citrus } \\
\text { Adana } \\
\text { Socio economic characteristics. } \\
\text { Farmer opinion }\end{array}$ \\
\hline
\end{tabular}

Türk Tarım - Gıda Bilim ve Teknoloji Dergisi 7(12): 2069-2074, 2019

\section{Adana İlinde İyi Tarım Uygulamaları Yapan ve Yapmayan Üreticilerin Genel Özellikleri ve İyi Tarım Uygulaması ile İlgili Görüşleri}

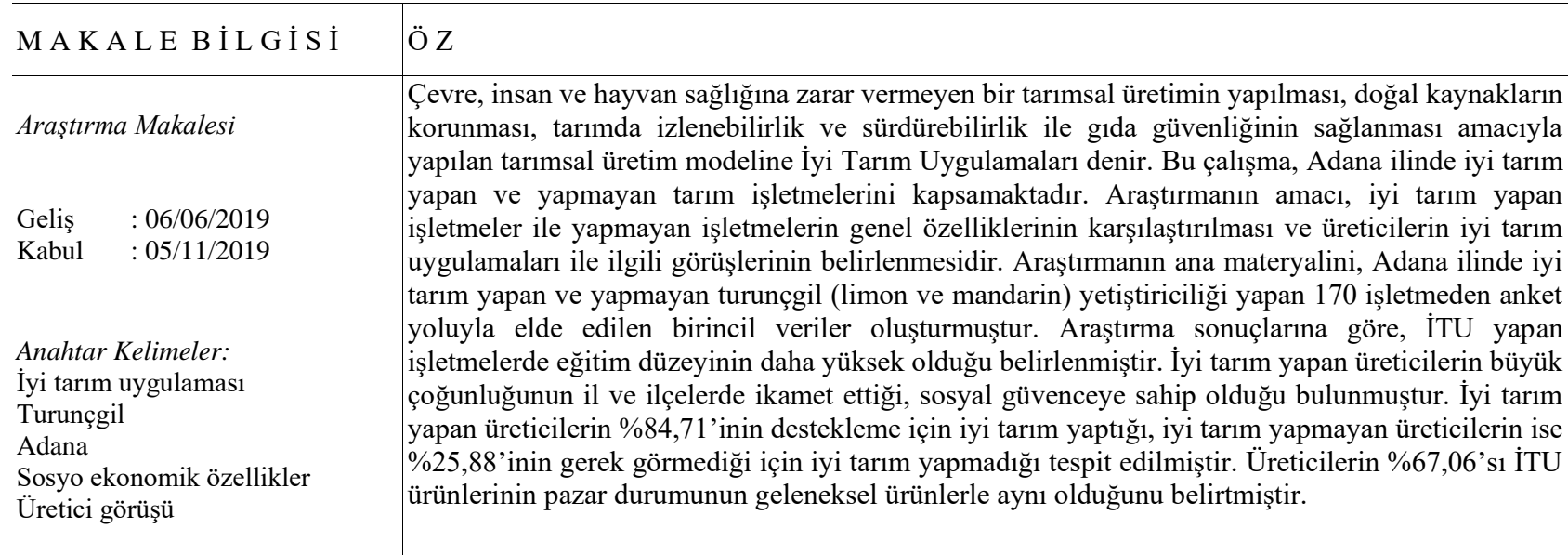




\section{Giriş}

Çă̆ımızın gerektirdiği tempolu yașamla birlikte, artan gelir düzeyi ve eğitim seviyesi, güvenli gıda tüketiminin de önemini arttırmıştır. Tüketiciler doğrudan tükettikleri tarımsal ürünler başta olmak üzere, satın aldıkları tüm gıda ürünlerinin güvenliğinden emin olmak ister hale gelmiştir. $\mathrm{Bu}$ bilinçle, gerek doğrudan tarımsal ürünlerin, gerekse işlenmiş gıda ürünlerinin güvenle üretildiğinin garantisini tüketicilere sunabilmek için, birtakım sistemler ve standartların oluşturulması ihtiyacı kaçınılmaz olmuştur.

FAO tarafindan, "tarımsal üretim sisteminin sosyal açıdan yaşanabilir, ekonomik açıdan karlı ve verimli, insan sağlığını koruyan, hayvan sağlık ve refahı ile çevreye önem veren bir hale getirmek için uygulanması gereken işlemler" olarak tanımlanan İyi Tarım Uygulamaları (İTU) konusundaki gelişmeler, Türkiye'de toplam tarımsal üretim ve ihracat miktarlarının iç ve dış pazarda rekabet edecek seviyeye ulaşmasında önemli rol oynayacaktır. Bu sayede dış pazara kaliteli güvenli ürün sunulurken, iç pazarda tüketicilerin sağlıklı ve güvenilir ürün tüketmeleri sağlanmış olacaktır (Anonim, 2014).

Ülkemizin 28.053.500 hektarlık alanının \%36’s1 tarıma uygun arazilerden oluşmaktadır. Tarıma uygun alan içerisinde, herhangi bir koruma önlemi gerektirmeyen 1. ve 2. sınıf özelliğe sahip araziler yer almaktadır. Ancak tarımsal potansiyeli yüksek olan bu araziler tarım dışı (sanayi, yerleşme, turizm, mera, orman alanı) kullanımı veya geleneksel hale gelmiş nadas, nadassız kuru tarım, yetersiz sulu tarım gibi bilim ve teknolojiden uzak yöntemlerden dolayı büyük ölçüde değerlendirilmemektedir. Tarımsal yöntemlerin geliştirilmesi; dünyada uygulanan yeni tarım tekniklerinin benimsenmesi ve ülkemizin başlıca sorunu olan küçük ölçekli arazilerin bütünleştirilmesiyle sağlanabilmektedir. Bu bağlamda İyi Tarım Uygulamaları (ITU) kaliteli ve kontrollü tarımsal üretimi teşvikte önemli rol oynamaktadır (Gözen, 2010).

Sayın (2002), tarafından yapılan çalışmanın sonucunda, EUREPGAP'ın ülkemiz çiftçisine ve ekonomisine sağlayacağı başlıca kazanımların daha verimli ve kaliteli üretim, yeni pazarlara giriş kolaylığ 1 , daha yüksek kazançlar ile çiftçi refahında sağlanan gelişmeler, çevreye duyarlı üretim ve doğal kaynak kullanımında denge olarak sıralanmıştır. Altunlu (2006), tarafından yapılan çalışmada, iyi tarım uygulamalarının basit bir tanımını yapmış ve ülkemizdeki durumuna dair tespitlerde bulunmuştur. Ülkemizde "İyi Tarım Uygulamaları" düzenlemelerinin başlamasından itibaren günümüze kadar olan dönemde karşılaşılan sorunlar ortaya konulmaya çalışılmıştır. Çalışma sonucunda ülkemizde EUREPGAP uygulamalarına entegrasyonda önümüze çıkacak başlıca sorunlar, arazi parçalılığ1 ve küçük işletme büyüklüğü, iç pazar talebinin düşüklüğü, eğitim ve donanımı düşük üretici yapısı olmak üzere sıralanmıştır. Sayın ve ark., (2015), tarafından yapılan çalışmada, Antalya ilinde iyi tarım uygulaması sertifikasıyla üretim yapan ve yapmayan örtüaltı sebze yetiştiricisi işletmelerinde iki grup arasında çiftçilik deneyim süreleri ve üye olunan örgüt sayıları yönünden $\% 5$ önem düzeyinde farklılık olduğu belirlenmiştir. Araştırma sonucunda, devlet desteğinin iyi tarım uygulaması yapmada teşvik edici etkisi olduğu anlaşıldığından destekleme uygulamasına devam edilmesi ve bu konuda üreticilere yönelik düzenlenen eğitimlerin etkin bir biçimde sürdürülmesi önerilmektedir.
Bunun yanında iç pazarda da iyi tarım uygulamaları ürünlerine olan talebi artırmaya yönelik görsel tanıtım ve yayım faaliyetleri yürütülmelidir. Özercan (2012), tarafından yapılan çalışmada, iyi tarım uygulamaları İzmir ili süs bitkileri yetiştiriciliği potansiyelinin ve uygulanabilirliğinin belirlenmesi amaçlanmıştır. Yapılan değerlendirme sonrasında İzmir ili süs bitkileri sektörünün en kuvvetli yönünün iklim koşullarının elverişli oluşu, lojistik konumu; zayıf noktaları olarak da pazarlamada yaşanılan sorunlar, üretim planı olmayışı, teknik bilgi eksikliği, geleneksel sera kullanım faaliyetleri olduğu belirlenmiştir. Yeni pazar olanakları ve oluşturulabilecek devlet destekleri bir firsat olarak değerlendirilmiş; iklimsel değişiklikler, hastalık ve zarlılarla mücadelenin zorlaşması, sulama suyu kalitesi düşüklüğü tehdit unsurlarından bazılarını teşkil etmiştir. Zayıf ve tehdit unsuru yaratan konularda iyileştirme çalışmalarının yapılması gerektiği belirlenmiştir. Aydın ve ark., (2017), tarafından yapılan çalışmada, Trakya Bölgesinde iyi tarım uygulaması yapan ve yapmayan üzüm üreten tarım işletmelerinin ekonomik olarak karşılaştırılması amaçlanmıştır. Araştırma bölgesinde ele alınan her iki grup üreticilerde verim ve maliyet açısından birbirine benzer sonuçlar çıkmıştır. Bunun nedeni olarak, iyi tarım uygulamaları yapan üzüm üreticilerinin her ne kadar ilaç, gübre ve sulama suyu uygulamalarını daha düşük miktarda ve bedelde yapmalarına karşılık ürün satış fiyatında farklılığın olmaması ve iyi tarım uygulamasındaki ekstra masrafların olmasından kaynaklandığını belirtmişlerdir. Aydın Eryılmaz ve Kılıç (2018a), yaptıkları çalışmada, Samsun ili Bafra ilçesinde konvansiyonel tarım yapan işletmelerin iyi tarım uygulamalarına geçmeleri halinde, optimum işletme organizasyonunda meydana gelen değişimin ortaya konulmasını amaçlamışlardır. Konvansiyonel tarımdaki optimum işletme organizasyonu doğrusal programlamayla, kimyasal gübre ve ilaç kullanımının sınırlandırıldığı iyi tarım uygulamalarındaki işletme organizasyonu ise hedef programlamayla tespit edilmiştir. Araştırma sonuçlarına göre konvansiyonel tarım yapan işletmelerde dekara 820,76 TL olan brüt kâr, planlama sonucunda \%31,07'lik artışla 1075,81 TL'ye çıkmıştır. İşletmelerin konvansiyonel tarımdan iyi tarım uygulamalarına geçmeleri halinde, hedef programlamayla elde edilen brüt kâr dekara 983,25 TL'dir. Bu durumda brüt kâr, konvansiyonel tarımdaki mevcut organizasyona göre $\% 19,79$ daha yüksek, ancak optimum işletme organizasyonuna göre \%8,60 daha düşük bulunmuştur. Bu sebeple iyi tarım uygulamalarının işletmeler tarafından benimsenmesinde, iyi tarım desteğinin brüt kârdaki azalmayı karşılaması büyük önem taşımaktadır. İyi tarım uygulamalarının yaygınlaşmasıyla, doğru zaman ve uygun miktarda girdi kullanılacağı için, iç ve dış pazarlara daha sağlıklı ürünlerin sunulacağını, aynı zamanda sürdürülebilir bir arazi yönetiminin de sağlanmış olacağını belirlemişlerdir.

Aydın Eryılmaz ve Kılıç (2018b), dünyada iyi tarım uygulamalarının gelişimi ve Türkiye'deki durumunu ortaya çıkarmak amacıyla yaptıkları çalışmada, iyi rarım uygulaması sonucunda, doğal kaynakların korunacağını, gelecekteki kuşaklar için sürdürülebilir bir üretim arzının garanti altına alınacağını ifade etmişlerdir. 
2018 yılı itibariyle Adana ili tarım alanının \%75,72'lik kısmını tahıllar ve diğer bitkisel ürünler alanı, \%15,27'lik kısmını meyve alanları, \%7,12'lik kısmını sebze alanları, $\% 1,86$ 'lık kısmını nadas alanları ve \%0,03'lük kısmını da süs bitkileri alanları oluşturmaktadır. 2018 yılı itibariyle Türkiye mandarin üretimi 1.650 .000 ton olup, Adana ilinde üretilen mandarin Türkiye üretiminin \%33,33'ünü oluşturmaktadır. Türkiye limon üretimi 1.100 .000 ton olup, Adana ilinde üretilen limon Türkiye üretiminin \%21,71'ini oluşturmaktadır (TÜİK, 2018).

Dünyada tarladan sofraya gıda güvenliği ve kalitesinin sağlanması amaciyla, ilk defa 1997'de Avrupa perakendeciler ürün çalışma grubu tarafından iyi tarım uygulamalarının çerçevesi belirlenmiştir (Polat, 2014; Aydın Eryılmaz ve Kılıç, 2018a). Türkiye'de iyi tarım uygulamalarına ilişkin ilk yönetmelik, 08.09.2004 tarih ve 25577 sayılı Resmi Gazetede yayınlanmıştır (Anonim, 2004). Ülkemizde iyi tarım uygulamaları faaliyetleri 2007 yılında başlamıştır. 2007 yılında 18 ilde, 651 üretici, 53.607 dekar alanda iyi tarım uygulamasına başlamış olup, 2018 y1lında bu rakamlar 63 il, 73.286 üretici, 6.156.137 dekar alana yükselmiştir. Araştırmanın yürütüldüğü Adana ilinde, 2007 yılında 30.455 dekar alanda iyi tarım uygulaması yapılır iken; 2010 yılında 439 üretici 360.535 dekar alanda, 2011 yılında 343 üretici 148.451 dekar alanda, 2012 yılında ise 378 üretici 169.095 dekar alanda iyi tarım uygulaması yapmışlardır. Son yıl verilerine baktığımızda 2007 yılında 30.455 dekar alanda iyi tarım uygulaması yapılırken; 2018 yılında 1.978 üreticinin 538.942 dekarda iyi tarım uygulaması yaptığı belirlenmiştir. 2007 yılında ülkemizde iyi tarım uygulaması yapılan alanın yaklaşık \%57'sini Adana ili oluşturmaktadır. 2018 yılında ise bu oran iyi tarım uygulaması yapılan il ve üretici sayısının artmasına paralel olarak yaklaş1k \%9 olmuştur. İTU'da Adana ili araştırmanın yürütüldüğü yıl olan 2012 yılı verilerine göre alan bazında ülke genelinde ilk sırada yer almaktadır. ITU'da sahibi olduğumuz bu ilk sirayı Kıyı Akdeniz Havzasında bulunan Yüreğir, Seyhan, Karataş, Kozan, Sarıçam, Ceyhan ve İmamoğlu ilçeleri kazandırmaktadır. $\mathrm{Bu}$ ilçelerde ağırlıklı olarak turunçgil ve yaş meyve sebze üretiminde İTU yapılmaktadır.

Araştırmanın amacı, iyi tarım yapan işletmeler ile yapmayan işletmelerin genel özelliklerinin karşılaştırılması ve üreticilerin iyi tarım uygulamaları ile ilgili görüşlerinin belirlenmesidir.

\section{Materyal ve Metot}

Araştırmanın ana materyalini, Adana ilinde iyi tarım yapan ve yapmayan turunçgil (limon ve mandarin) yetiştiriciliği yapan işletmelerden yüz yüze görüşme yapılarak anket yoluyla elde edilen veriler oluşturmaktadır.
Adana İl Tarım ve Orman Müdürlüğü kayıtlarına göre, çalışmanın yürütüleceği 2012 yılına temel teşkil etmesi bakımından Adana ilinde iyi tarım uygulamalarının en fazla turunçgil yetiştiriciliğinde olduğu tespit edilmiştir. Turunçgil yetiştiriciliğinde iyi tarım yapanların en fazla olduğu Yüreğir ve Seyhan ilçeleri seçilmiştir. Seçilen ilçelerde iyi tarım yapanların turunçgillerden limon ve mandarin yetiştiriciliğinde yoğun olduğu belirlenmiştir. Yüreğir ilçesinde limon ve mandarinde iyi tarım yapan 120 işletme, Seyhan ilçesinde de 22 işletme olduğu tespit edilmiştir. Her iki ilçede de bu işletmelerin yaklaşık \%60'ının limon ve mandarin yetiştiriciliğini birlikte yaptıkları saptanmıştır. Dolayısıyla hem limon hem de mandarinde iyi tarım yapan Yüreğir ilçesinde 72, Seyhan ilçesinde de 13 işletme olmak üzere toplam 85 işletmenin tamamı ile anket çalışması yapılmıştır. İyi tarım yapan ve yapmayan işletmelerin karşılaştırılabilmesi için aynı bölgede benzer özellikte iyi tarım yapmayan limon ve mandarinle beraber yetiştiren 85 işletme ile de görüşülmüştür.

Elde edilen verilerin analizinde ortalama, yüzde gibi basit hesaplama ve çapraz tablolardan faydalanılarak; anket yapılan üreticilerin yaş, eğitim, ailedeki birey sayısı, mesleki deneyimleri, tarım dışı faaliyette bulunup bulunmadıkları, ikamet ettikleri yer, sosyal güvence durumlarını içeren genel özellikleri belirlenmeye çalışılmıştır. Ayrıca araştırma alanında üreticilerin iyi tarım uygulamaları hakkında bilgi ve görüşleri elde edilmiştir.

Çalışmada, İTU yapan ve yapmayan gruplar için elde edilen sürekli ancak normal dağılım gösteren veriler $\mathrm{t}$ testine tabi tutularak gruplar arasında farklılık olup olmadığı incelenmiştir.

\section{Araştırma Sonuçları ve Tartışma}

Tarımsal üretim özellikle işletme sahiplerince üretim kararının verilmesi, üretim tekniği ve bunun geliştirilmesi bakımından farklılıklar gösterebilmektedir. İşletme sahibinin yaşı, eğitimi, mesleki deneyimi ve tarım dişı faaliyette bulunma durumu gibi işletme sahibi ile ilgili genel bilgiler bu aşamada önem arz eder.

Görüşülen 170 işletmecinin \%54,71'i 50 yaşın üzerinde $\% 34,12$ 'si 36 ile 50 yaş arasında ve \%11,18'i 35 yaşın altındadır. İyi tarım uygulaması (İTU) yapan işletmecilerin $\% 62,35$ 'i, iyi tarım yapmayan işletmelerin \%47,06's s yaşlı üreticilerden oluşmaktadır (Çizelge 1).

Araştırma sonuçlarına göre, işletme sahibinin ortalama yaşı İTU yapan işletmelerde 56,78 yıl, İTU yapmayan işletmelerde ise 50,87 y1l olarak belirlenmiştir. İyi tarım uygulayan ve uygulamayan üreticilerin yaşlarının farklılığının istatistiki olarak önemli olup olmadığını tespit etmek üzere yapılan t testi sonucunda $\% 1(p=0,003)$ anlam düzeyinde farklılık olduğu belirlenmiştir.

Çizelge 1 Üreticilerin yaş durumlarına göre dağılımı

Table 1 Distribution of producers by age

\begin{tabular}{ll|cccccc}
\hline \multirow{2}{*}{} & \multirow{2}{*}{ Yaş } & \multicolumn{2}{c}{ İTU yapan } & \multicolumn{2}{c}{ İTU yapmayan } & \multicolumn{2}{c}{ Toplam } \\
\cline { 3 - 7 } & & İşletme sayıs1 & $\%$ & İşletme sayı1s1 & $\%$ & İşletme say1S1 & $\%$ \\
\hline Genç & $(<35)$ & 6 & 7,06 & 13 & 15,29 & 19 & 11,18 \\
Orta Yaşlı & $(36-50)$ & 26 & 30,59 & 32 & 37,65 & 58 & 34,12 \\
Yaşlı & $(51+)$ & 53 & 62,35 & 40 & 47,06 & 93 & 54,71 \\
Toplam & & 85 & 100,00 & 85 & 100,00 & 170 & 100,00 \\
\hline
\end{tabular}


Çizelge 2 Üreticilerin mesleki deneyimlerine göre dağılımı

Table 2 Distribution of producers by professional experience

\begin{tabular}{lc|rrrrrr}
\hline \multirow{2}{*}{ Mesleki deneyim } & \multicolumn{2}{c}{ İTU yapan } & \multicolumn{2}{c}{ ITU yapmayan } & \multicolumn{2}{c}{ Toplam } \\
\cline { 3 - 8 } & & İşletme say1s1 & $\%$ & İşletme say1s1 & $\%$ & İşletme say1s1 & $\%$ \\
\hline Düsük & $(1-10)$ & 22 & 25,88 & 13 & 15,29 & 35 & 20,59 \\
Orta & $(11-20$ y1l & 15 & 17,65 & 22 & 25,88 & 37 & 21,76 \\
Yüksek & $(21+)$ & 48 & 56,47 & 50 & 58,82 & 98 & 57,65 \\
Toplam & 85 & 100,00 & 85 & 100,00 & 170 & 100,00 \\
\hline
\end{tabular}

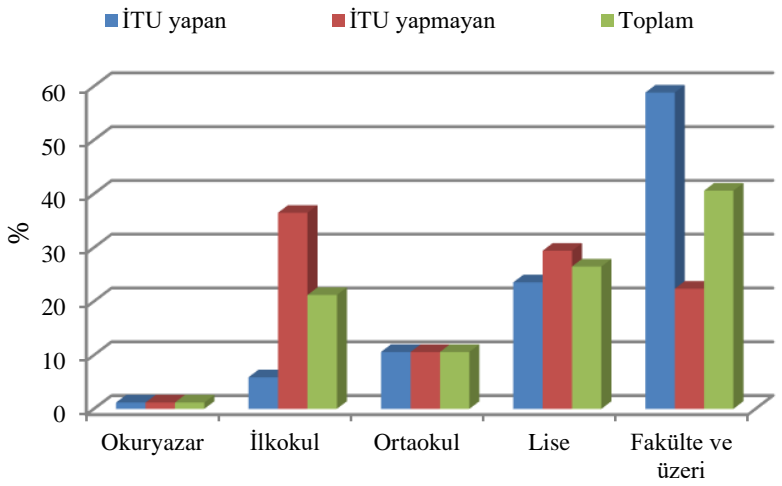

Şekil 1 Üreticilerin eğitim durumuna göre dağılımı Figure 1 Distribution of manufacturers by education

Üreticilerin \%40,59'u fakülte ve üzeri okullardan mezunken $\% 26,47$ 'si lise, $\% 21,18$ 'i ilkokul, \%10,59'u ortaokul ve \%1,18'i okuryazar durumundadır. İTU yapan işletmelerde eğitim düzeyi daha yüksek olup fakülte ve üzeri eğitime sahip olanların oranı \%58,82'dir. İTU yapmayan işletmecilerin \%36,47'si ilkokul mezunudur (Şekil 1).

ITTU yapan işletmecilerin eğitim süresi ortalama 12,56 y1l, İTU yapmayan işletmecilerin eğitim süresi de 9,27 yıldır. İyi tarım uygulayan ve uygulamayan üreticilerin eğitim sürelerinin farklıllğının istatistiki olarak önemli olup olmadığını tespit etmek üzere yapılan $t$ testi sonucunda $\% 1(\mathrm{p}=0,000)$ anlam düzeyinde farkl1lık olduğu belirlenmiştir.

Ele alınan bölgede görüşülen üreticilerin $\% 57,65$ 'i 4 veya 5 bireyli işletmelerdir. \%26,47'sinde birey sayısı 1 ile 3 arasındadır. $\% 15,88^{\prime}$ inde ise birey sayısı 6 kişi ve üzerindedir. Tarımsal uygulamaları yapan işletmelerin çoğunluğu orta sayıda bireyli işletmelerdir. İTU yapan işletmelerin $\% 56,47$ 'si, ITTU yapmayan işletmelerin $\% 58,82$ 'si 4 veya 5 bireyli işletmelerden oluşmaktadır (Şekil 2).

İncelenen işletmelerde hane halkı genişliği İTU yapanlarda ortalama 3,82 kişi, İTU yapmayanlarda ise 4,71 kişi olarak belirlenmiştir. İyi tarım uygulayan ve uygulamayan üreticilerin hane halkı genişliğinin farklılı̆̆ının istatistiki olarak önemli olup olmadığını tespit etmek üzere yapılan $\mathrm{t}$ testi sonucunda $\% 1(\mathrm{p}=0,002)$ anlam düzeyinde farklılık olduğu belirlenmiştir.

Araştırma yapılan bölgede yapılan anket çalışması sonucunda işletmecilerin mesleki deneyimlerine bakıldığında $\% 57,65$ 'inin mesleki deneyim süreleri 21 yıl ve üzerindedir. \%21,76'sının ise mesleki deneyimleri orta derecede olup 11 ile 20 yıl arasindadır. \%20,59'unun deneyim süreleri de 1 ile 10 yıl arasındadır. İyi tarım uygulaması yapan ve yapmayan işletmelerin yarıdan fazlasının mesleki deneyimleri yüksek grubunda olup 20 yılın üzerindedir (Çizelge 2).



Şekil 2 Üreticilerin ailedeki birey sayıs1 Figure 2 Number of producers in the family

Çalışmada, işletme sahibinin tarımsal deneyimi İTU yapanlarda ortalama 26,85 yll, ITU yapmayanlarda ise 27,24 y1l olarak belirlenmiştir.

Araştırma sahasında görüşülen işletmecilerin $\% 64,71$ 'inin tarım dışı işi olmadığ ve \%35,29'unun ise tarım dışı işi olduğu belirlenmiştir. Üreticilerin büyük bir kısmı sadece tarımsal üretim yapmaktadır. İyi tarım uygulaması yapan işletmecilerin \%32,94'ünün, yapmayan işletmecilerin ise $\% 37,65$ 'inin tarım dış1 işi olduğu saptanmıştır. Ele alınan bölgedeki üreticilerin tarım dışı faaliyette bulunma durumları ile tarımsal uygulamalar arasında istatistiki fark bulunmamaktadır.

Bölgede yapılan benzer bir çalışmada, işletmecilerin ortalama yaşlarının 45,30 yıl, eğitim süreleri $6,7 \mathrm{y}$ 1l, tarımsal üretim deneyimlerinin 28,90 y1l olduğu ve işletmecilerin ortalama olarak \%24,70'nin tarım dışı iş yapmakta olduğu belirlenmiştir (Demirtaş, 2005).

Tarım dışı faaliyette bulunan toplam 60 işletmecinin $\% 38,33$ 'ü serbest meslekte çalışırken, \%28,33'ü esnaf, $\% 13,33$ 'ü emekli, \%10,00'u memur, \%5,00'i doktor, $\% 1,67$ 'si işçi, \%1,67'si mimar ve \%1,67'si de muhtardır. İyi tarım uygulaması yapan üreticilerin \%39,29'u esnaf iken iyi tarım yapmayan üreticilerin $\% 43,75$ 'i serbest meslekte çalışmaktadır.

Araştırma bölgesindeki üreticilerin ikamet ettikleri yerleri incelediğimizde işletmecilerin $\% 81,18$ 'i il ve ilçelerde ikamet ederken, \%18,82'si köylerde ikamet etmektedir. İyi tarım uygulaması yapan üreticilerin \%7,06's1 köylerde yaşarken, yapmayan üreticilerin \%30,59'u köylerde ikamet etmektedir. Buna göre iyi tarım yapan üreticilerin büyük çoğunluğunun il ve ilçelerde ikamet ettiğini söyleyebiliriz (Çizelge 3).

Bölgedeki üreticilerin $\% 98,24$ 'ünün sosyal güvencesi var iken, \%1,76'sı sosyal güvenceye sahip değildir. İyi tarım uygulaması yapan üreticilerin tamamı sosyal güvenceye sahipken, yapmayan üreticilerin de çok küçük bir bölümü $(\% 3,53)$ sosyal güvenceye sahip değildir. 
Çizelge 3 Üreticilerin ikamet ettikleri yere göre dağılımı

Table 3 Distribution of manufacturers by place of residence

\begin{tabular}{l|cccccc}
\hline \multirow{2}{*}{ İkamet ettikleri yer } & \multicolumn{2}{|c}{ İTU yapan } & \multicolumn{2}{c}{ İTU yapmayan } & \multicolumn{2}{c}{ Toplam } \\
\cline { 2 - 7 } & İşletme sayıs & $\%$ & İşletme say1s1 & $\%$ & İşletme sayıs1 & $\%$ \\
\hline Köy & 6 & 7,06 & 26 & 30,59 & 32 & 18,82 \\
İlçe-il & 79 & 92,94 & 59 & 69,41 & 138 & 81,18 \\
Toplam & 85 & 100,00 & 85 & 100,00 & 170 & 100,00 \\
\hline
\end{tabular}

Çizelge 4. İTU İle İlgili Görüş ve Düşünceler

Table 4 Opinions and ideas about ITU

\begin{tabular}{l|cc}
\multicolumn{1}{c|}{ İTU ile ilgili görüş ve düşünceler } & \multicolumn{2}{c}{ ITU yapan } \\
\cline { 2 - 3 } & İşletme sayısı & $\%^{*}$ \\
\hline Destekleme miktarı arttırılmalı & 30 & 47,06 \\
Ruhsatlı ilaç sayısı artmalı & 38 & 44,71 \\
ITTU ürünlerine pazar fiyatı farkı olmalı & 34 & 40,00 \\
Pazarlamada kolaylı olmalı & 11 & 12,94 \\
Sertifikasyon kuruluşları da denetlenmeli & 6 & 7,06 \\
Eğitim yayım çalış̧aları yapılmalı & 5 & 5,88 \\
ITTU zorunlu hale getirilmeli & 2 & 2,35 \\
\hline
\end{tabular}

*: Birden fazla seçenek işaretlenmiştir.

Çalışmada, İTU yapan üreticilerin üye oldukları örgüt say1s1 ortalama 2,31 iken İTU yapmayan üreticilerde ortalama 1,69 çıkmıştır. İyi tarım uygulayan ve uygulamayan üreticilerin üye oldukları örgüt sayısının farklılığının istatistiki olarak önemli olup olmadığını tespit etmek üzere yapılan $\mathrm{t}$ testi sonucunda $\% 1(\mathrm{p}=0,000)$ anlam düzeyinde farklılık olduğu belirlenmiştir.

İyi tarım uygulamaları ile üretim yapan üreticilere neden yapıyorsunuz sorusu sorulmuş ve birden fazla seçenek işaretlemelerine izin verilmiştir. Buna göre üreticilerin $\% 84,71$ 'i destekleme için, $\% 49,41$ 'i çevreye zararı az olduğu için, \%38,82'si kaliteli ürün elde ettikleri için, \%35,29'u işçilerin güvenliği için, \%28,24'ü her aşamasında denetlendiği için ve $\% 22,35$ 'i de daha fazla ürün elde ettiği için iyi tarım uygulaması yapmaktadır.

İyi tarım uygulamaları ile üretim yapmayan üreticilere neden yapmiyorsunuz sorusu sorulmuş ve birden fazla seçenek işaretlemelerine izin verilmiştir. Buna göre üreticilerin $\% 25,88^{\prime} \mathrm{i}$ gerek görmemektedir. $\% 23,53$ 'ü maliyeti fazla olduğu için, \%23,53'ü her aşamada denetlendiği için, \%11,76'sı konvansiyonel tarımdan daha fazla ürün elde ettiği için, \%10,59'u arazisi az olduğu için, $\% 4,71$ 'i konu hakkında bilgi sahibi olmadığı için, \%2,35'i fiyat avantaj1 olmadığ 1 için, \%2,35'i pazar avantajı az olduğu için, \%1,18'i arazisi hisseli olduğu için iyi tarım uygulamasinı tercih etmemektedir.

Yapılan çalışma sonucunda, üreticilerin \%67,06's İTU ürünlerinin pazar durumunun geleneksel ürünlerle aynı olduğunu, \%18,82'si bugün sınırlı ama gelecekte daha iyi olacağını, $\% 8,24$ 'ü pazar şansının yüksek ve $\% 5,88$ 'i de pazar şansının düşük olduğunu belirtmiştir.

2013 Aralık ayında Adana ilinde düzenlenmiş olan "İyi Tarım Uygulamalarının Mevcut Durumu, Sorunları ve Çözüm Önerileri Çalıştayı" raporuna göre İTU'da pazarlama sorunlarına yönelik İTU ürünlerini tüketici ayırt edebilmeli ve tercih edebilmeli, İTU ürünlerine özerk satış yerleri ve stantları oluşturulabilmeli, İTU ürünlerine barkod uygulaması getirilebilmeli, İTU ürünleri reklam ve tanıtım programları ile ön plana çıkarılabilmeli şeklinde çözüm önerileri getirilmiştir (Anonim, 2013).
2009 yılında, 2008 y1lı içerisinde İyi Tarım Uygulamaları çerçevesinde üretim yapan ve ürünlerini sertifikalandıran üreticilere, ürün grubu ve üretim şekli ayrımı yapılmaksızın $18 \mathrm{TL} / \mathrm{da}$ destekleme ödemesi yapılmıştır. Sonraki yıllarda sadece yaş meyve sebze üretiminde ve ürün ayrımı yapılmaksızın örtü altında yapılan tarımsal üretimde İyi Tarım Uygulamaları kriterlerine göre üretim yapan ve bunu sertifikalandıran üreticilere yönelik destekleme uygulamasına geçilmiştir. Bunu izleyen y1llarda 2009 yılında meyve sebzeye 15 $\mathrm{TL} /$ da ve örtü altına $75 \mathrm{TL} / \mathrm{da}, 2010$ ve 2011 y1llarında meyve sebzeye $20 \mathrm{TL} / \mathrm{da}$ ve örtü altına $80 \mathrm{TL} / \mathrm{da}, 2012 \mathrm{ve}$ 2013 yıllarında meyve sebzeye $25 \mathrm{TL} / \mathrm{da}$ ve örtü altına 100 TL/da, 2014 yılında meyve sebzede $50 \mathrm{TL} / \mathrm{da}$ ve örtü altında $150 \mathrm{TL} / \mathrm{da}, 2015$ ve 2016 yıllarında meyve sebzede $50 \mathrm{TL} / \mathrm{da}$, örtü altında $150 \mathrm{TL} / \mathrm{da}$ ve süs bitkileri, tıbbi aromatik bitkilerde $100 \mathrm{TL} / \mathrm{da}$ destekleme miktarı belirlenmiştir. 2017 yılından itibaren ise iyi tarım uygulamaları desteklemelerinde bireysel ve grup sertifikasyonuna göre destek miktarları değişiklik göstermiştir. Buna göre 2017 y1lında meyve sebzede bireysel $50 \mathrm{TL} / \mathrm{da}$ ve grup $40 \mathrm{TL} / \mathrm{da}$, süs bitkileri, tıbbi aromatik bitkilerde bireysel $100 \mathrm{TL} / \mathrm{da}$ ve grup $80 \mathrm{TL} / \mathrm{da}$, örtü altında bireysel ve grup sertifikasyonunda $150 \mathrm{TL} / \mathrm{da}$ ve çeltikte bireysel ve grup sertifikasyonunda $10 \mathrm{TL} / \mathrm{da}$ destekleme miktarı belirlenmiştir. 2018 yılında ise meyve sebzede bireysel $50 \mathrm{TL} / \mathrm{da}$ ve grup $40 \mathrm{TL} / \mathrm{da}$, süs bitkileri, tıbbi aromatik bitkilerde bireysel $100 \mathrm{TL} / \mathrm{da}$ ve grup 50 $\mathrm{TL} / \mathrm{da}$, örtü altında bireysel ve grup sertifikasyonunda 150 TL/da ve çeltikte bireysel ve grup sertifikasyonunda 10 TL/da destekleme miktarı belirlenmiştir (Anonim, 2019).

İncelenen bölgedeki iyi tarım uygulaması yapan 85 üreticinin iyi tarım uygulaması hakkındaki düşünceleri araştırılmış̧ır. İşletmecilerin \%47,06's1 destekleme miktarlarının arttırılması, \%44,71'i ruhsatlı ilaç sayısının artması, \%40,00'1 İTU ürünlerinde pazar fiyatı fark1 olması, \%12,94'ü pazarlamada kolaylık olması, \%7,06's1 sertifikasyon kuruluşlarının denetlenmesi, \%5,88'i eğitim yayım çalışmalarının yapılması ve $\% 2,35$ 'i de iyi tarım uygulamasının zorunlu hale getirilmesi gerektiğini 
söylemişlerdir (Çizelge 4). İlaç ruhsatlandırmalarında ve doz ayarlamalarında AB ile eş uygulamalar getirilebilir.

\section{Sonuç}

İTU yapan işletmelerde fakülte ve üzeri eğitime sahip olanların oranı yaklaşık \%60,00’a yakındır. Eğitim düzeyleri arttıkça iyi tarım uygulaması yapma oranının artmakta olduğu ve bu değişkenin istatistiki $(p<0,01)$ olarak anlamlı olduğu saptanmıştır. İyi tarım yapan üreticilerin daha fazla sayıda örgüte üye oldukları bunun da sosyal katılım ve çevresel ilişki açısından olumlu sonuçlar doğurabileceği düşünülebilir. Bölgede iyi tarım uygulaması yapan üreticilerin büyük bir kısmı $(\% 74,12)$ ürettikleri ürünlerin pazar durumunun geleneksel ürünlerle aynı durumda olduğunu ifade etmişlerdir. $\mathrm{Bu}$ durumda, ITU ürünlerini tüketicinin ayırt edebilmesi ve tercih edebilmesi için reklam ve tanıtım programlarına ağırlık verilerek İTU ürünlerinin ön plana çıkması sağlanmalıdır. Üreticilerin ITU eğitimi alarak bilgi ve uygulama kapasitelerinin genişlemesi sağlanabilir. İTU yayım programları oluşturulabilir ve bu çerçevede kurs, seminer gibi etkinlikler düzenlenebilir.

İyi tarım uygulamaları ile üretim yapan üreticilerin $\% 84,71$ 'i destekleme için iyi tarım yaptıklarını belirtmişlerdir. Bu sonuç, desteğin iyi tarım uygulaması yapmada teşvik edici etkisinin olduğunu göstermekte ve destek miktarının artmasına bağlı olarak iyi tarım yapanların sayısının artacağına işaret etmektedir. ITU ürünlerinin desteklenmesinde sadece yaş meyve sebze üretimi ve ürün ayrımı yapılmaksızın örtü altında yapılan tarımsal üretim desteklenmekte olup tarla bitkilerinin de destekleme kapsamına alınması gerekmektedir. Ayrıca İTU'nın yayılması için İTU ürünleri fuarlarda, festivallerde, organizasyonlarda vurgulanarak farkındalık oluşturulmalıdır.

\section{Kaynaklar}

Altunlu S. 2006. Tarım ve Mühendislik, Sayı:75-79.

Anonim. 2004. T.C. Resmi Gazete. http://www.resmigazete.gov.tr /eskiler/2004/09/20040 908.htm (Erişim Tarihi: 02.10.2019).

Anonim. 2013. Adana Tarım İl Müdürlüğü İyi Tarım Uygulamalarının Mevcut Durumu, Sorunları ve Çözüm Önerileri Çalıştayı Raporu, Adana.

Anonim. 2014. belgelendirme.ctr.com.tr/iyi-tarim-uygulamalarinedir.html (Erişim tarihi: 09.02.2019).

Anonim. 2019. T.C. Tarım ve Orman Bakanlığı Kayıtları.

Aydın B, Kiracı MA, Aktürk D, Özkan E, Hurma H. 2017. Üzüm üretiminde iyi tarım uygulamalarının ekonomik analizi: Trakya bölgesi örneği. Türk Tarım ve Doğa Bilimleri Dergisi 4(4): 402-408.

Aydın Eryılmaz G, Kılıç O. 2018a. İyi tarım uygulamalarının konvansiyonel tarım yapan işletmelerdeki optimum organizasyona etkisi: Samsun ili Bafra ilçesi örneği. ADÜ Ziraat Derg, 15(1):101-106.

Aydın Eryılmaz G, Kılıç O. 2018b. Türkiye'de sürdürülebilir tarım ve iyi tarım uygulamaları. KSÜ Tarim ve Doğa Derg 21(4): 624-631.

Demirtaş B. 2005. Türkiye'de limon üretim ekonomisi ve pazar yapısı. Ç.Ü. Fen Bilimleri Enstitüsü, Tarım Ekonomisi Anabilim Dalı, Doktora Tezi, Adana.

Gözen H. 2010. Seracılık üretimi faaliyetlerinde iyi tarım uygulamaları: Kıbrıs Magosa Örneği. Namık Kemal Üniversitesi Fen Bilimleri Enstitüsü Yüksek Lisans Tezi, Tekirdağ.

Özercan E. 2012. İzmir ili süs bitkileri yetiştiriciliğinde iyi tarım uygulamaları potansiyelinin değerlendirilmesi. Ege Üniversitesi Fen Bilimleri Enstitüsü Doktora Tezi, İzmir.

Polat F. 2014. Azerbaycan'da global GAP tarım uygulamalarının gıda güvenliği bakımından değerlendirilmesi, Azersun örneği. XI. Ulusal Tarım Ekonomisi Kongresi, 3-5 Eylül, Samsun.

Sayın C. 2002. Yaş meyve ve sebze dış ticaretinde sağlık düzenlemeleri ve EUREPGAP uygulamaları. Panel Sunuş Notlar, Elmalı, Antalya.

Sayın B, Çelikyurt MA, Kuzgun M, Aydın B, 2015. Antalya ilinde örtüaltı yetiştiriciliği yapan üreticilerin iyi tarım uygulamalarına yaklaşımı. Derim, 32(2): 171-186.

TÜİK. 2019. www.tuik.gov.tr (Erişim tarihi: 13.04.2019). 